\title{
IUELTAL
}

\section{Basic Need Analysis in Practical English Grammar: An Effort on Creating and Empowering Autonomy Learners}

\author{
Dwi Astuti Wahyu Nurhayati \\ State Islamic Institute of Tulungagung, Indonesia \\ e-mail:dwiastuti@iain-tulungagung.ac.id;dwiastuti507@gmail.com
}

\begin{abstract}
:
This paper presents the students' need analysis in Practical English Grammar course. The data were collected through questionnaires and interview by individual or group assessment. It involves 34 Indonesian undergraduate students who were majoring in English, took, join Grammar class and conducted classroom interaction in English teaching and learning process in IAIN Tulungagung, East Java, Indonesia. The data were analyzed using descriptive qualitative approach. The finding revealed some students' perspectives on Practical English Grammar course (lack of learning media, ineffective teaching strategy, unsupportive class atmosphere, and Grammar as difficult course); some student-considered effective ways to learn Practical English grammar (YouTube, discussion, appropriate learning techniques, progress report, peer assessment, and game); and students' results on their need analysis in learning Practical English Grammar in form of independent option on: learning media, learning strategy, learning material, and creating own questions and its answers.
\end{abstract}

Keywords: need analysis, practical English grammar, students' perspective

\section{Introduction}

English has spread widely and is studied by many people around the world. It makes English as the most used language and dominates some aspects in language include: technology, information, trade, education, business, health, and commerce. Srinivas (2019) explained that in the present globalization world, English dominates in almost all the sectors that make a necessity to discuss its role as a global language. According to reasons above, it makes people thronged in learning English as it is considered that it brings good future to individual 
who want to come up in life. Knowledge of English is necessity in order to recruit qualified persons especially in job opportunity in professional world. Nishanti (2018) declared that many major countries would open jobs for those who master English Language. Although being skillful in English does not totally measure someone's success, having sufficient knowledge of English will make one through any profession (Pandey \& Pandey, 2014).

In seeking ability of English, there are four skills to be mastered: speaking, writing, listening, and reading; and some proficiency such as: grammar, vocabulary, and pronunciation. One of the most important aspects to be able in English is grammar. Grammar is rules to how language should be arranged using various categories. Grammar or structure generally refers to a set of rules characterizing the correct order of words in the degree of sentence (Handayani \& Johan, 2018). By having ability in grammar, someone can be easily to construct words into sentences with the correct meanings.

In Indonesia, English is treated as foreign language. As foreign language, it is obvious that not all of Indonesian understand well about English. In covering that gap, in Indonesia English is taught starting from kindergarten until university levels. In these recent years, it occurs that grammar is difficult aspect to be studied of English. It often makes Indonesian students get confused and bored in learning grammar. Some learners might confuse with the complexity of Grammar that make them not able to absorb material given by teachers. As in tenses, there are many kinds of tenses in English Grammar that tend to be memorized by students. Dealing with their strategies in learning Grammar, it might necessary to rebuild and recreate techniques to teach Grammar. However, sometimes the anxiety in studying grammar is occurred from internal and external aspects. From internal aspect, it could be students are not interested in meanwhile the external aspect might be the teachers' strategies used in teaching grammar. In order to solve this issue, it is needed useful and joyful way for students to learn grammar. It can both increase students' interest in learning and teachers' effective way to teach grammar.

Some experts have conducted studies dealing with Grammar teaching. Effendi et. al. (2017) conducted study on Grammar teaching at an English Education Department in Universitas Ahmad Dahlan. It aimed to discover the approach used in teaching grammar, find students' Grammar ability, and discuss the students' difficulties in studying Grammar. The result of the study declared that students were quite suitable with lecturers' strategies in teaching Grammar that is by providing formula firstly in learning Grammar. It was also gained that students faced some problems in learning Grammar especially in the term of different structure between Indonesian and English and some basic parts such as: tenses, adverb, and prepositional phrases. From that result, Effendi et. al. (2017) concluded that level of students' Grammar mastery of English Education was fair.

Then, Uibu \& Liiver (2015) held study aimed to discover the causes of students' Grammar mistakes, teachers' practices to correct students' Grammar mistakes and teacher-considered most effective strategies to prevent students' mistakes. The study that involved Estonian teachers presented that prior reason of students' Grammar mistakes was the lack of students' cognitive skills included orthography, syntax, and sentence's purpose of communication. It was also found that some practices were used to solve the problem that is by providing understanding and analysis for syntax and discussion for sentence's purpose of communication. Not only that, the study also presented teachers' strategies to prevent 
grammar mistakes namely: repeating and illustrating for the aim of sentence in communication and illustrating, repeating, and explaining for orthographic mistakes.

Furthermore, a study concerned about Grammar teaching and learning also conducted by AlMekhlafi and Nagaratnam (2011). The study focused to investigate teachers and students' difficulties in teaching and studying Grammar especially in EFL concept. It was discovered that both teachers and students faced difficulties dealing with EFL Grammar whether in spoken or written communication. The students dominated in experiencing difficulties than students. However, it suggested that it was needed to create focused study of difficulties faced by teachers and students in specific method, arranging techniques to solve them, and implement the method that suit with the teaching and learning environment.

\section{Literature Review}

Educational Learning English might not be separated from language structure. Language structure is the hardest concern to bargain with. It is built by way of various modern rules related to sentence production. It can moreover be utilized as the device to alter and analyze sentence developments. No wonder why a few students sense overburdened whereas acing English grammar. A few college students, on the opposite, considers that linguistic use is very challenging. That's why they can't hold up to have a address room discourse on English linguistic use, indeed they make a little bunch specializing talking around grammar. Nowadays, students don't must sense bored in picking up information of English language structure since the propels in innovation. The tremendous developing utilize of web gives benefits to the understudies in examining linguistic use. They can discover online language structure instructional exercises effortlessly and make utilize of it. They can alter their language structure dominance level with instructive or rationalization given. Most students feel affected this way, a number of them still choose upon school room rationalization wherein they can effectively have interaction in the event that inconveniences emerge. (Bahruddin, 2015)

Grammar is one of the tree crucial components in getting to know English. In learning English, the students are implied to have dialect aptitudes and talk competency. In getting to know English, the students are assumed to have dialect aptitudes and talk competency. Grammatical competence is needed in fulfilling talk competence since the understudies are able of create linguistically adjust sentences or articulations by being bumbling on this portion. Language structure is rules for shaping expressions and making sentences. It ought to be learned with the help of college students so that it'll be able to set up English word into exact sentences. Linguistic use possesses a central position, due to the fact while we don't secure language structure, we are ready to induce challenges in picking up information of and learning a few dialect abilities. Agreeing to (System, 2010) by means of analyzing language structure approaches, inexperienced people are able of make a sentence from expressions and how to organize sentences come to be paragraph. Within the teaching of grammar, the teachers ought to ensure whether the scholars have been able of utilize their grammatical knowledge to create sentences or not. Hence, learning language structure must center not handiest on structure but too the utilization and its implies.

The college students furthermore accepted that so that it will master a dialect, it was critical to require a see at language structure. On the other hand, more instructors than college students accepted that it was higher to work out dialect in recreated genuine life 
circumstances than to consider linguistic bureaucracy expressly (Pazaver, 2009). Linguistic use is dialect structure which is needed by utilizing the human beings to decide what the implied which means of words and sentences. These frameworks include phonology (the sound of dialect), sentence structure (courses of action of words into huge units), morphology (shape of words), Pragmatics, and Semantics (Implications of dialect). These all frameworks are had to encourage understudies to create their dialect capabilities' execution. (Yang, 2004). Language structure in keeping with Rutheford (1987) is "a basic perspective of any dialect educating programme" (p.9), and so performs an pivotal position in dialect learning. Be that as it may, the center on linguistic use in dialect coaching was challenged with the development of instructing strategies essentially based on one-of-a-kind mastering speculations, Such a challenge affected not easiest the substance and the educational programs in dialect educating, but furthermore the suggestion for educating language structure. In this way a new ponder language structure was vital causing etymologists and dialect teachers to reexamine the status of linguistic use in dialect learning. This brought approximately a steady talk about among dialect teachers and language specialists with respect to the nature and kind of language structure planning, which influenced the understanding of how second dialects have to be be instructed or found (Rohani, 2017). Language structure educating has as a rule been a totally questionable subject interior the teach of 2 nd dialect procurement. Whether or now not to instruct language structure remains an uncertain issue. Be that as it may, there has been a not abnormal agreement within the course of the esteem of educating language structure. Learners require grammar consolidated into communicative sports to reach each familiarity and exactness. Other than, the part of linguistic use instruction has moreover been raised from the point of view of students' and instructors' discernments (Landolsi, 2011)

Greenbaum and Nelson (2002) outline grammar as the set of rules that allow individuals to combine expressions in a dialect into bigger units. Additionally, Greenbaum and Nelson (2002) say a few points of interest of picking up information of English linguistic use. To begin with, the ubiquity of syntactic frameworks is frequently vital for accentuations. Second, a take a see at of one's local language structure is valuable while one investigate the linguistic use of a remote dialect. Third, it's distant valuable interior the elucidation of scholarly as well as nonliterary writings since the elucidation of a entry now and then depends upon urgently on linguistic examination. Fourth, it's distant advantageous in composition. Other benefits of picking up information of English language structure were proposed by Derewianka in Emilia (2014) who notices that acing English linguistic use has the taking after points of interest: (1) to reflect on how the English dialect works, (2) to have a shared language for talking almost the most capabilities of the English dialect, (3) to get it how syntactic frameworks makes special shapes of which suggests, (4) watch design of dialect and word choices to basically look at writings, (5) with a see to utilize dialect successfully, accurately and precisely. In advance, she contends that a know-how of linguistic use can offer assistance newbies to extremely assess their individual content and those of others, e.g. figuring out point of see; analyzing how language may be controlled to realize positive comes about and part the peruser in a specific way; knowing how dialect can be utilized to amass a specific recognizable proof or a specific way of seeing the world.

The strategies linguistic use must first-class learn vary from educator to coach, analyst to analyst, and methodologist to methodologist. As of now in 2nd dialect writing, approaches 
to linguistic use educating that are frequently said are Center on Shape and Center on Shapes. The previous alludes to a strategy to teaching grammar each time blunders emerge for the length of a meaning-centered movement, whereas the last mentioned alludes to instructing language structure in segregation. (Thu, 2009) Within the way of educating grammar, there are essential approaches which have been utilized for a beautiful long period of time; the deductive and inductive strategy. These two methods are called conventional strategy by implies of most professionals in linguistic use educating. Customarily, language structure educating is seen as the introduction and hone of discrete syntactic structures (Ellis, 2006). The potential to utilize language structure precisely, definitively and accurately is needed for English learner to communicate both in verbal and composed way. What is to compose down and talk ought to be based on redress language structure, in arrange that the message passed on can be caught on (Mestari, 2016).

\section{Research Methodology}

The The researcher utilized descriptive qualitative as a investigate strategy. It is subjective since it bargains with the characteristic wonder. This subjective investigate included gathering information which portrayed the clarification into sentences. Agreeing to (Creswell, 2016), subjective investigate is graphic in what the analyst is curious about prepare, meaning, and understanding picked up through word or picture.

The subject of this study are English Students of 3 rd semester IAIN Tulungagung. There were 34 respondents taken from two classes. They had been chosen on the presumption that they've surpassed grammar educating and got numerous experienced for the length of the course. They were purposively chosen on the suspicion that they had passed all dialect linguistic use classes and nearly wrapped up all language skill classes in which they were assumed to apply syntactic information they had examined. The study was conducted in IAIN Tulungagung beginning from August till December 2019.

There are two methods for collecting information in this study were distributing questionnaires and interview. Distributing questionnaires is strategy that suitable to apply on the off chance that there were a parcel of subjects. The second method in collecting the information utilized interview. Interview could be a way to gather information utilized get data specifically from source. 15-20 minutes interview sessions had been performed with a few volunteers, who had been respondents to the questionnaire administered. The method of reasoning for utilizing focused on semi subordinate open-ended interviews turned into to secure the respondents' point of see instead of make generalizations.

The sources of information are subject where information can be gotten. In this research there were two forms of the information. They were information which assembled from distributing questionnaires and the result of interview around the students' perspective in practical English grammar. The strategy of examining information that's utilized in this research is Creswell's theories by doing taking after steps (Creswell, 2009): 1. Planning the information for examination. 2. Perusing and understanding. 3. Coding and classifying the information (expression). 4. The following step in information investigation includes making an elucidation or meaning of the data. 5. The ultimate steps is Drawing conclusions. 


\section{Findings}

Based on this study, some efforts need to be conducted in order to solve and decrease students' lack of interest in learning Practical English Grammar and motivate them to understand more. The responses of students who are taught Practical English Grammar course are described for various perspectives. Then, students' considered effective ways to study Practical English Grammar were also explained. According to the issues, some students' need analysis were also presented as one of some results from this study.

\subsection{Students' Perspective on Practical English Grammar Course}

The study discovered some perspectives of students on Practical English Grammar course. The chart below showed the perspectives of students in learning Practical English Grammar at university. It was found that there are four major perspectives: lack of learning media $(17 \%)$, ineffective teaching strategy (35\%), unsupportive class atmosphere $(28 \%)$, and Grammar as difficult course (20\%).

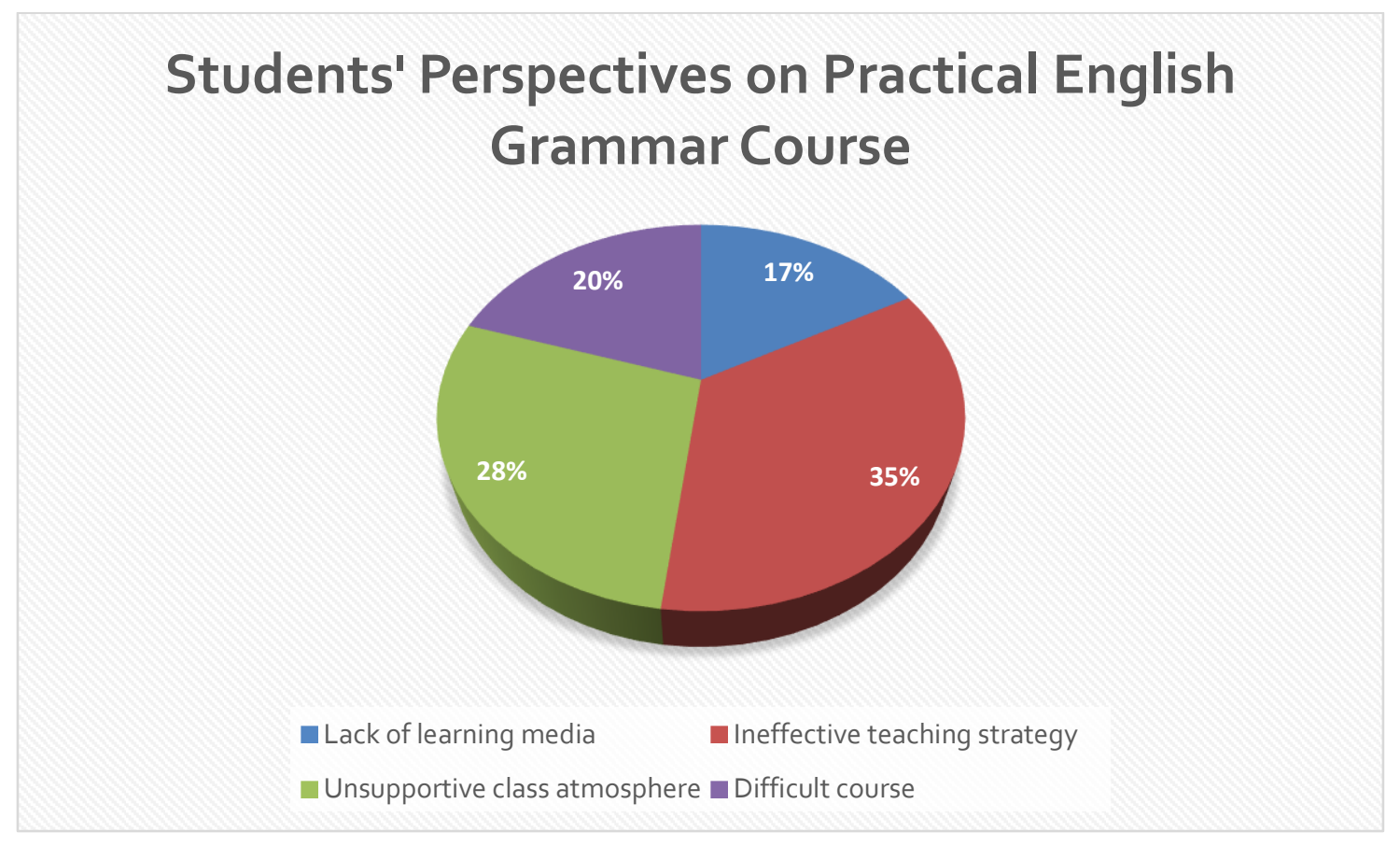

Firstly, ineffective learning strategy got the highest perspective from students. That is about $35 \%$ students revealed that in learning Practical English Grammar, they experienced ineffective, waste-full, and inappropriate strategy used by lecturer to teach Grammar. The inappropriate learning strategy could be in form of one sided learning which lecturer fed students only without any comments from students that make students less active in contributing to learning process. It was agreed by about 12 students of $\mathrm{TBI}_{3} \mathrm{G}$.

Secondly, unsupportive class atmosphere also one of major perspectives showed by students. It was about $28 \%$ or 10 students from $\mathrm{TBI}_{3} \mathrm{G}$ who declared that class situation when learning Practical English Grammar were held did not support their learning as in unsupportive learning media (laptop, speaker, LCD, projector), the crowded class with too much students, and noises from within class, other classes or surroundings. 
Then, the statement that Grammar included into difficult course was explained by $20 \%$ students. About 7 students stated that learning Practical English Grammar was difficult according to formulas and other rules from Grammar they believe to be remembered. Some rules provided by grammar (tenses, passive voice, conditional sentences) that were agreed by these students make them feeling difficult and confused in absorbing the material regarding to Grammar.

Finally, the lack of learning media in learning Practical English grammar was agreed by $17 \%$ or about 6 students of TBI $3 \mathrm{G}$ class. The reason was they have limited sources to learn Grammar. However, the rest of the students were having no problem dealing with learning media. They stated that some learning websites and applications from the Internet (as in YouTube, Kahoot, and Cake Application) are enough to support their learning.

Meanwhile, the interview also showed some students' point of view on Practical English Grammar Course. Alfina explained that the learning process was not interesting due to the lack of delivering variations.

The Grammar learning I've got in elementary, junior, and high school were delivered unattractively and with use students' paperwork only. Therefore, it made me feel bored as well as difficult to understand the formula (of Grammar) because of that problem. (Alfina)

Then, the same reason was also admitted by Annisaul. She also explained that the strategy used in teaching Grammar was not effective.

Learning Grammar in my previous studies felt difficult, bored, and unattractive to be understood. The strategy used in learning Grammar was only one-way communication that is teacher explaining the material without any feedback or participation from students. (Annisaul)

In addition, Ayuning declared that lack of participation and evaluation in learning process caused low understanding and minimum material-acquisition.

By the lack of participation especially in classroom, students became less in understanding the task given by lecturer, less in assessing the good and not good presentation. Lack of reprimand towards presentation's process and result also made students could not improve themselves as expected before due to less examples and not creative thinking. (Ayuning)

\subsection{Students' Perspective on the effective Strategies in Practical English Grammar Course}

The following result was the perspectives of students on the effective ways of strategies in Practical English Grammar course. The result interpreted that it was gotten six considered effective strategies in learning Practical English Grammar course. The detailed explanation was provided below: 


\section{Effective Strategies in Practical English Grammar Course}
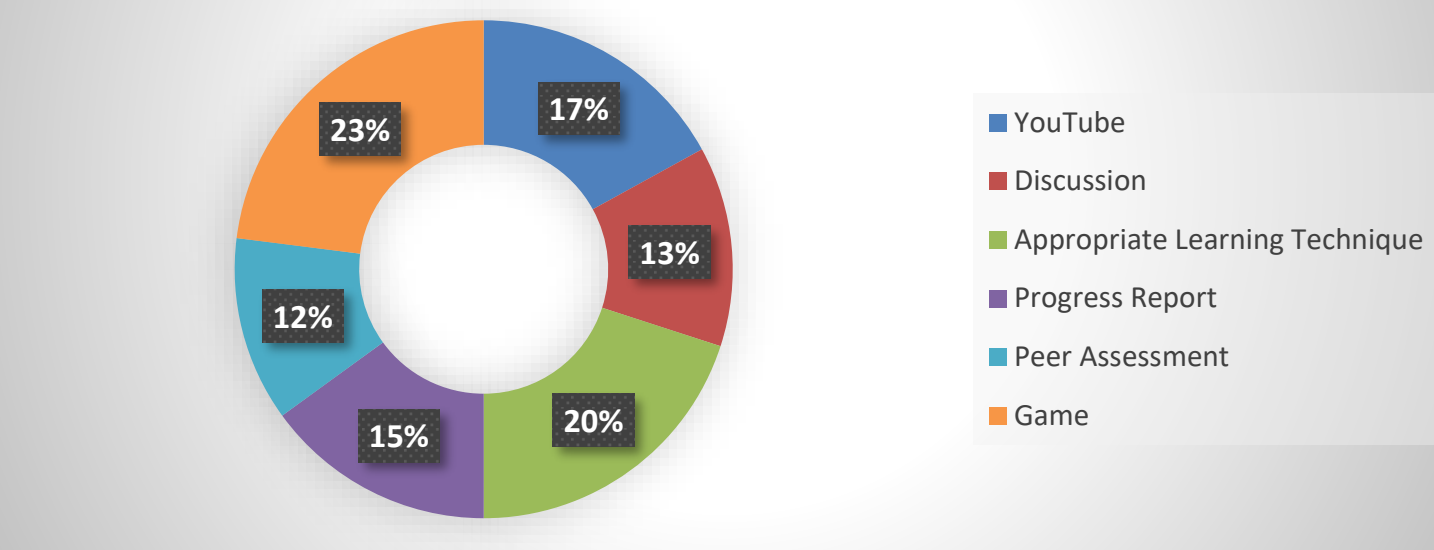

The first one is that about $23 \%$ students of $\mathrm{TBI} 3 \mathrm{G}$ agreed that learning Practical English Grammar through game was more interesting and understandable. Games in cellular phone application such as Kahoot, Hello English, Cake, were considered by students as interesting media to improve in learning Grammar. The next is appropriate learning technique that needs to be upgraded. Students suggested that some learning techniques or strategies such as Jigsaw, Scaffolding, and Mind-mapping, were looked upon to be implemented in order to create good learning process. This was approved by $20 \%$ students of $\mathrm{TBI} 3 \mathrm{G}$. Then, the next effective strategy from students' perspectives is learning through YouTube media. About 17\% students concluded that learning Practical English Grammar through YouTube are easy and interesting since it is provided in audio-visual form. From YouTube, it was divided into three main parts of video: beginning, middle, and last. Most of students in harmony chose the middle of the video as the most effective part to learn Practical English Grammar. Progress report was also included into the effective way to learn Practical English Grammar. 15\% students of TBI 3 G declared that in order to achieve good understanding in the course, it is needed report of progression in learning the course. Therefore, the students can understand and know their deficiencies in studying Grammar and improve them. Moreover, about $13 \%$ students stated that discussion was also effective in learning process of Practical English Grammar. In discussion, students agreed that they can argue, giving suggestion, rebuttal or addition in material regarding to Grammar. In addition, $12 \%$ students of $\mathrm{TBI} 3 \mathrm{G}$ agreed that peer assessment also can be used as effective strategy in learning Practical English Grammar. By peer assessment, students became more motivated as their classmates assess them and they would try to learn seriously as it affects their assessment.

\subsection{Students' Result on Need Analysis in Practical English Grammar Course}

Students' need analysis in Practical English Grammar course was also presented in this study. There are four students' results of need analysis: independent option on learning media, independent option on learning strategy, independent option on learning material, and 
creating own questions and its answers. The further description is presented in pie chart below:

\section{Students' Need Analysis in Practical English Grammar Course}

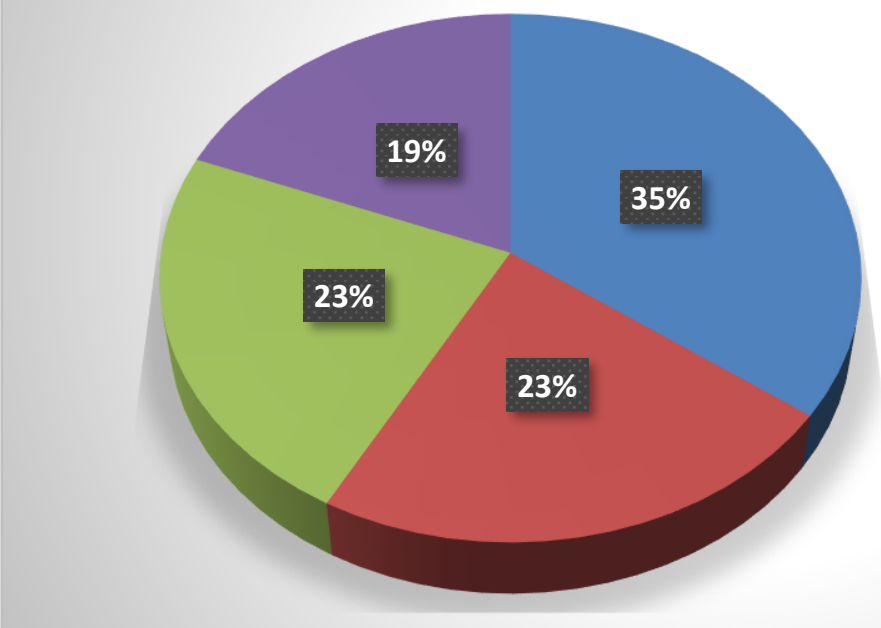

- Independent option on learning media

Independent option on learning strategy

Independent option on learning material

- Creating own questions and answers

The first result of students' need analysis was about 35\% students of TBI $3 \mathrm{G}$ agreed that choosing learning media by themselves help them learning English Grammar easily and joyfully. They explained that media they chose to study Grammar, as in YouTube videos, songs, and learning website provided by the Internet made Grammar more understandable. Then, about $23 \%$ students stated that choosing strategy to be used in learning Practical English Grammar independently made them motivated and having enthusiasm. Students declared that from three kinds of learning strategy (Jigsaw, scaffolding, and mind-mapping), Jigsaw was considered by students as the most effective technique in learning Practical English Grammar, although some of them also use combined strategy which one of them is Jigsaw. Furthermore, the other $23 \%$ students believed that determining their own material facilitated them in learning Practical English Grammar. Materials which come from the Internet were preferred by students than from textbooks. However, not all of them spontaneously apply materials from the Internet only, but they combined it with school books or class discussion. In addition, some students chose to create questions and its answers to make sure they understand Practical English Grammar well. About $19 \%$ students of $\mathrm{TBI}{ }_{3} \mathrm{G}$ implemented writing questions and provided the answers directly. They believed that by that the more they can answers the questions, the more understand they were towards materials from Practical English Grammar.

In addition, the interview also showed some students' point of view on the need analysis of Practical English Grammar Course.

I conducted needs analysis and the result showed that students were given freedom to: collect their own material, choose their medium and techniques, creating questions and answers, and RPP. The aims are to make students easily understand Grammar practically, increasing students' confident, honesty, teaching practice, creating joyful learning environment, and appreciating other people's efforts and competency. (Wahdatul) 
In my opinion, Grammar learning is difficult because we have to know and understand every formula of Grammar. Once or second times of teachers' explanation might not giving obvious impact, therefore we need to review again the material. Lecturer also needs to create innovation in classroom so that Grammar can be attractive learning subject. For example, in the previous meeting, I asked teacher to order students to create their own strategies in group to explain material to their group friends. If there were found any mistakes, lecturer could corrects them. For instance, every group has different material and then they will be rearranged again so that every student can understand every material from different friends. (Bella)

\section{Discussion}

\subsection{Students' Perspective on Practical English Grammar Course}

The finding from the study provides students' perspectives on Practical English Grammar course. From 34 students, 35\% said that strategies used by lecturer were not effective. Lecturers tent to be the source of information while students only listen towards lecturers' explanation or this is called teacher-centered, so that students felt boredom. Emaliana (2017) said that the practice of student-centered in teaching needs to be considered whether there is necessary to modify and update the classroom teaching and learning practice. However, as lecturers become the most dominant participant in the classroom as experienced by $\mathrm{TBI}{ }_{3} \mathrm{G}$, it needs to be looked the benefits of combining the teaching strategies. Emaliana (2017) on the result of her study also said that the students suggested to apply both strategies (teachercentered and student-centered) in form of combination, as there was found that no essential teacher-centered or student-centered approach will be effective in teaching and learning process. Then, the next high perspective of students is about the students' complains about the class size. They admitted that the learning environment especially total amounts of student in the class affect their study. Mpho (2018) explained that most teachers in large class sized used teacher centered in delivering the knowledge that make students passive learners. This leads to ineffective learning which is explained previously that create no maximum the learning outcomes. Learning outcomes are concept of what the student is expected to achieve and how the student is expected to exhibit this achievement as a result of participation in learning process (Schreurs \& Dumbravenau, 2014).

\subsection{Students' Perspective on the effective Strategy in Practical English Grammar Course}

From the result, the highest perspective on effective strategy to use in Practical English Grammar course is learning through games. It is proved by $23 \%$ student. Bakan \& Bakan (2018) argued that in Game-based learning, the student tries to solve the problem by choosing between alternatives appropriate for his/her learning style. Study through games is expected to provide effective learning environment in order to be remembered in memory. The result also indicates that $20 \%$ students give argument about the important of teaching strategy. They expect some strategies to be implemented in teaching process. Supriusman (2014) suggested that Grammar can be taught by explaining the grammar rules, providing grammar with practice in mastering patterns of Grammar through analogy process, and giving students opportunities to use English in real world situation. Knowledge and skills of method and techniques are important to be comprehended by teachers, so that they can use appropriate method and technique in teaching Grammar. Navaz \& Sama (2017) on the result of their study explained that some different ways can be used to teach grammar, such as: prescribed text books, self-prepared games, presentations, group discussion, and games. 


\subsection{Students' Result on Need Analysis in Practical English Grammar Course}

The results of finding indicate that the majority of students prefer to choose learning media by themselves such as youtube, videos, songs, and learning website. According to Bikowski (2018) students can be trained to analyze language using a concordancer and look for specific grammatical features. Video transcripts can also be used as a type of authentic discourse which students can be trained to analyze for grammar and vocabulary use. The structures they find can be added to individualized grammar logs for future analysis. Analysis of texts can be further expanded into using translations provided by online translators, with students comparing their translations to computer-generated translations in order to reflect on their own grammar choices as well as the practicality of using online translators for their future communication. These types of activities provide increased student control and flexibility. One of the ways to fulfill this goal is to use authentic audiovisual materials in teaching grammar. Using videos which are a multidimensional text containing both visual and audio content would be very effective (Saeedi \&Biri, 2016).

Harmer (2001) mentions two reasons why video can add a special dimension to the language learning experience. First, by seeing language in use learners' comprehension will be greatly enhanced since meanings and moods are often conveyed through visual clues. Second, videos offer students opportunities to look at situations far beyond their classroom, thus raising their cultural awareness. The students also have their own strategy in learning English grammar. Some of them claimed that they were motivated and having enthusiasm in studying. The choice of the appropriate strategy has also been found to ensure success in further language learning as it helps to learn a language more effectively (Thornbury, 1999 in Uibu \& liiver, 2015). There were considerable logic to affirm the implication of learner autonomy confidence for English learning at universities (Alrabai, 2017; Alzubi et al, 2017). Early, as research consequences have divulged, autonomous learning drive to greater desire to enroll a a language ( $\mathrm{Li}, 2015 ;$ Tseng and Schmitt, 2008). Then, studies (Dogan and Mirici, 2017; Hu and Zhang, 2017; Kameli et I., 2013; Phan and Hamid, 2017; Tuan, 2011) have displayed that teacher's practice of autonomous learning strategies reinforces advancement of EFL learners' language aptitude. Hence, English teacher or lecturers prerequisite to set up the categorization of autonomous learning accesses that accelerate students' learning improvement.

The decision in determining their own material in practical English grammar influence student's understanding, it is in with Almusharraf's research (2018) who examines that some of the examples of activities pertaining to how they exposure English experience in creating any various materials. It means that the students will be responsible for their option and indirectly love the materials. In the last students implemented writing questions and answers in testing their understanding towards the materials.

\section{Conclusion}

Based on the results of research and discussion, it can be concluded that in the case of students' perspective on practical English grammar course, almost all of students said that strategies used by lecturer were not effective. They felt bored toward teacher center approach. Then the effective strategy in practical English grammar is game based learning because they are enjoy and it can increase the memorizing automatically. The students prefer to choose learning media by themselves. In this case they used technology to support their 
learning such as YouTube, songs, and learning website. Besides students also have their own strategies and determine the material by themselves. Indirectly it is influenced toward students' understanding in studying grammar. The last there were students who made questions and answers toward the materials.

\section{References}

Almusharraf, N. (2018). English as a foreign language learner autonomy in vocabulary development. Journal of Research in Innovative Teaching \& Learning, 11 (2).159-177.

Alrabai, F. (2017). Exploring the unknown: the autonomy of Saudi EFL learners, English Language Teaching, 10 (5), 222-223.

Alzubi, A.A.F., Singh,M.KM. \& Pandian, A. (2017). The use of learner autonomy in English as a foreign language context among Saudi undergraduates enrolled in preparatory year deanship at Najran University, Advances in Language and Literary Studies,8(2),152-160.

Bahruddin. (2015). Enhancing Students' Motivation in Learning English Grammar through A Computer-Supported Learning Classroom Management. Journal of English Education and Linguistics Studies, 2(2), 85-107.

Bakan, Ugur \& Bakan, Ufuk. (2018). Game-Based Learning Studies in Education Journals: A Systematic review of Recent Trends. Actualidades Pedagogicas, (72), 119-145.

Bikowski, D. (2018). Technology for Teaching Grammar. The TESOL Encyclopedia of English Language Teaching.

Creswell, J. (2009). Research Design:Qualitative, Quantitative, and Mixed-Method Approaches. Third Edition, Sage Publication.

Creswell, J. (2016). Research Design: Qualitative, Quantitative, And Mixed-Method Approaches. Fourth Edition. Yoyakarta: Pustaka Belajar.

Dogan, G., \& Mirici,I.H. (2017). EFL instructors' perception and practices on learner autonomy in some Turkish universities. Journal of Language and Linguistic Studies, 13 (1), 166-193.

Effendi, S., Rokhyati, U., Rachman, U. A., Rakhmawati, A. D., \& Pertiwi, D. (2017). A Study on Grammar Teaching at an English Education Department in an EFL Context. International Journal on Studies in English Language and Literature (IJSELL), 5(1), 42-46.

Emaliana, Ive. (2017). Teacher-centered or Student-centered Learning Approach to Promote Learning?. Jurnal Sosial Humaniora, 10(2), 59-70.

Emilia, Emi. (2014). Introducing Functional Grammar. Jakarta: Pustaka Jaya.

Greenbaum, S., \& Gerald,N. (2002). An Introduction To English Grammar: Second Edition. London: Longman.

Handayani, Nurmadhona \& Johan, Muhammad. (2018). Problem Faced in Grammar of EFL Students. Open Journal System, Khazanah Ilmu Berazam, 1(2), 33-41.

Harmer, J. (2001). The Practice of Language Teaching. Endinburgh: Longman.

Hu,P. \& Zhang,J. (2017). A pathwy to learner autonomy: a self-determination theory perspective. Asia Pacific Education Review, 18(1), 147-157.

Kameli, S.K.Mostapha, G.G., \& Baki, R.R. (2012). The influence of formal language learning environment on vocabulary learning strategies. Journal of Language Teaching a\& Research, 3 (1), 23-29.

$\mathrm{Li}, \mathrm{X}$. (2015). A studyon college English teachers' role in developing learner autonomy. Practice in Languge Studies, 5 (2), 435-441. 
Liiver, Merili \& Uibu, K. (2015). Students' grammar mistakes and effective teaching strategies. International Journal of Teaching and Education, 3(1), 2015.

Mestari, S.A. (2016). The Use of Authentic Materials in Teaching Grammar for EFL Students (Teachers' Perspective). Llt Journal, 19(2).

Mpho, Otukile-Mongwaketse. (2018). Teacher centered dominated approaches: Their implications for today's inclusive classrooms. International Journal of Psychology and Counselling, 10(2), 11-21.

Navaz, AMM and Sama, FRF. (2017). Teaching Grammar in the English Language Classroom: Perceptions and Practices of Students and Teachers in the Ampara District. Proceedings of 7 th International Symposium SEUSL, 653-667.

Pandey, Meenu and Pandey, Prabhat. (2014). Better English for Better Employment Opportunities. International Journal of Multidisciplinary Approach and Studies, 1(4), 93100.

Pazaver, A. (2009). Asian Students' Perceptions of Grammar Teaching In the ESL Classroom. The International Journal of Language Society and Culture, 27, 27-35

Phan,T.T.H. \& Hamid,M.O. (2017). Learner autonomy in foreign language policies in Vietnamese universities: an exploration of teacher agency from a sociocultural perspective, Current Issues in Language Planning, 18 (1), 39-56.

Rohani, S. (2007). Teaching of Grammar: Teachers' Beliefs, Instructional Contexts and Practices. Dissertation. Universiti Sains Malaysia kualalumpur.

Saeedi, Z. \& Biri, A. (2016). The application of application of technology in teaching grammar to EFL learners: The role of animated sitcoms. Teaching English with Technology, 16(2), 18-39.

Schreurs, J., \& Dumbraveanu, R. (2014). A Shift from Teacher Centered to Learner Centered Approach. iJEP, 4(3), 36-41.

Srinivas, P. R. (2019). The Role of English as A Global Language. Research Journal of English (RJOE), 4(1), 65-79.

Supriusman. (2014). Methods and Techniques of Teaching Grammar in ELT. SELT Padang, 430-437.

Thu, T.H. (2009). Teachers' Perceptions about Grammar Teaching. Alliant International University.

Tseng, W.T. \& Schmitt, N. (2008). Toward a model of motivated vocabulary learning: a structural equation modeling approach. Language Learning, 58(2), 357-400.

Tuan,L.T. (2011). An empirical research on self-learning vocabulary. Theory and Practice in Language Studies, 1 (12), 1688-1695.

Uibu, K., \& Liiver, M. (2015). Students' Grammar Mistakes and Effective Teaching Strategies. International Journal of Teaching and Education, 3(1), 70-78.

Yang, C. D. (2004). Universal Grammar, Statistics or Both? Trends in Cognitive Sciences. Accessed on 25 February, 2020 in Https://Doi.Org/10.1016/J.Tics.2004.08.006 